\title{
Effect of Salinity Stress on Coriander (Coriandrum sativum) Seeds Germination and Plant Growth
}

\author{
Alaa El-Din Sayed Sayed Ewase*, Samira Omran, Soad El-Sherif , and \\ Nagat Tawfik \\ *Department of Botany, Faculty of Science, Sirte University, Libya.
}

\begin{abstract}
A pot experiment was carried out to study the effect of salinity stress on seeds germination and plants growth of Coriander (Coriandrum sativum L.) by the selection method. For this purpose, four treatments of different concentrations of $\mathrm{NaCl}$ were used, namely, $0,1000,2000,3000$, and $4000 \mathrm{ppm}$ of $\mathrm{NaCl}$. The following parameters of: seeds germination, roots number and length, plant strength, number of leaves, plant length, shoot tip necrosis, and the percentage of survivals were recorded. The Obtained results showed that all growth parameters were reduced by increasing the $\mathrm{NaCl}$ concentration except for the percentage of shoot tip necrosis which was increased with a significant difference among all treatments. Coriander plants were found to resist salinity up to the concentration of $3000 \mathrm{ppm} \mathrm{NaCl}$ only.
\end{abstract}

Keywords: Coriander, Coriandrum sativum, Seeds, germination, Plant growth, salinity, NaCl, Salt, tolerant.

\section{INTRODUCTION}

Coriander (Coriandrum sativum) which belongs to family Apiaceae (Umbelliferae), is a herb which possesses nutritional and medicinal properties, besides, it is one of the most commonly used spices. The first medicinal uses of the plant were reported by the ancient Egyptians. Both leaves and seeds of the plant are used for medicinal purpose. Coriander contains many active principles primarily monoterpenes, \& pinene, limpene, ý-terpinene, p-Cymene, borenol, Citronellol, camphor, geraniol, coriandrin, dihydrocoriandrin, coriandrons A-E, flavonoids, and essential oils. Coriandrum sativum has been reported to have several pharmacological effects such as antifertility, antihyperglycemic, antihyperlipidemic, antioxidant, antiproliferative, hypotensive, and digestive stimulant. Coriander is also used in detox diet. It helps to remove toxic mineral residue, such as mercury and lead and excretes them in the urine or faces, (Leena et al., 2012).

Salinity is one of the most serious and widely spread agricultural problem resulting to the loss of yield and arable land. One strategy available to cope with the saline soil is to choose salt-tolerant crops or to select salt-tolerant cultivars within a crop, (Morpurgo, 1991).

Salt stress is one of the most serious limiting factors for crop growth and production in the arid regions. About $23 \%$ of the world's cultivated lands is saline and $37 \%$ is sodic (Khan and Duke, 2001). Selection and breeding of salt tolerant plants is becoming an option to minimize the negative impact of salinity (Epstein et al., 1980). Considerable research work has been conducted on the effect of salinity on different growth characters of different crops worldwide (Boyer, 1982; Hanson and Hitz, 1982; Munns and Termatt, 1986; Munns, 2005; Munns, 1993; Khavari- Nejad and Mostofi, 1998; Essa, 2002; FAO, 2002; Maghsoud et al., 2008; Ashraf, 2009; Cha-um et al., 2011; Nasser, 2012; Moradi and Zauareh, 2013; and Zeinoalbedin, 2012). 
The aim of this study was to detect the effect of salinity stress on seeds germination and plants growth of Coriander (Coriandrum sativum) and to evaluate its tolerance to salinity levels.

\section{MATERIALS AND METHODS}

In this experiment, the effect of salinity stress using sodium chloride $(\mathrm{NaCl})$ on both Coriander (Coriandrum sativum) seeds germination and growth in vivo was studied. Five treatments of $\mathrm{NaCl}$ were used. The different concentrations of $\mathrm{NaCl}$ were added to distilled water, these concentrations are: 0, 1000, 2000, 3000, and 4000 ppm NaCl, respectively. Coriander seeds (Figure 1) were grown in pots (size $25 \mathrm{~cm}$ ) and 2-3 cm depth, filled with peat moss and sand (2:1). The seeds were irrigated with the last $\mathrm{NaCl}$ concentrations. Irrigation with the previous concentrations continued for 21 days from seeds germination until plants collecting. Data were recorded including: seeds germination, roots number and length, plant strength, number of leaves, plant length, shoot tip necrosis, and the percentage of survivals.

For both plants strength and shoot tip necrosis, degrees were given to the plants using the method described by Klein and Livingston (1982). In this method, the plants were rated from culture on 0 to 5 relative growth scale as shown in Table (1).

Table 1: Descriptive grades used for determination of the in vitro relative growth of potato explants (Klein and Living, 1982).

\begin{tabular}{|c|l|}
\hline Rating & \multicolumn{1}{|c|}{ Description } \\
\hline 0 & The cultures turned brown and appeared to be invisible. \\
\hline 1 & $\begin{array}{l}\text { The culture stills green, showed no readily observable growth and } \\
\text { development differentiation from the initially excised tissue. }\end{array}$ \\
\hline 2 & One or two leaves were evident. \\
\hline 3 & More than two leaves were evident. \\
\hline 4 & The culture showed evidence of shoot formation and development. \\
\hline 5 & Both shoots and roots have been developed. \\
\hline
\end{tabular}

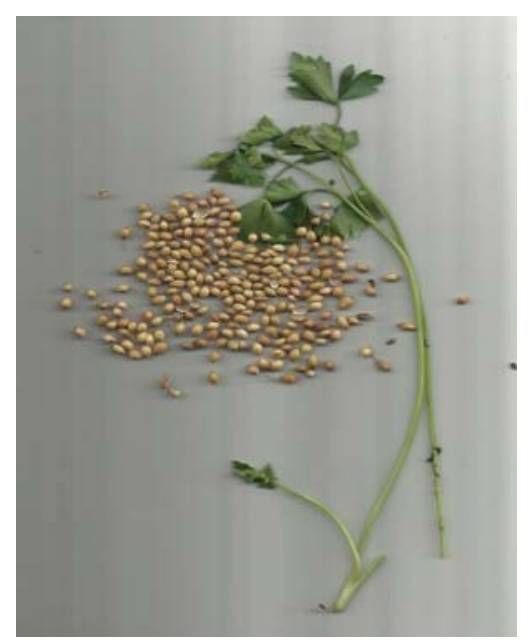

Fig. 1: Coriander seeds and plants cultivated in Libya.

After 21 days, data were recorded including seeds germination and all growth parameters of all treatments of coriander plants (Figure 2).

The experimental design consisted of five salinity levels replicated five times in a completely randomized plot design. 
Data of Coriander seeds germination and growth characters were statistically analyzed and the means were compared using L.S.D. according to the method described by SAS (1990).

\section{RESULTS AND DISCUSSION}

Data in Table (2) and in Histogram (Figure 3) showed that Sodium chloride $(\mathrm{NaCl})$ reduced all the studied parameters including: seeds germination, plant length, number of leaves, plant strength, roots number, root length, and percentage of survivals, with a significant difference among all treatments. So, increasing $\mathrm{NaCl}$ concentration leads to more reduction in seeds germination percentage and plant growth rate, also, it leads to a decreasing in the percentage of survivals. While the percentages of shoot tip necrosis is increased by the increase of $\mathrm{NaCl}$ concentration. In case of the $\mathrm{NaCl}$ concentration $5000 \mathrm{ppm}$, there is no any germination occurred. In general, the adverse effect of salinity linearly increased with the increase in its concentration. These results are in harmony with El-Barkouki (2000) who mentioned that sodium chloride reduced the percentage of survivals. However, Levy et al., (1988), after working with potato reported that salinity tended to lower water and osmotic potentials of leaves and tubers while increasing the content of total soluble solids and proline. It also increased the content of dry matter and reduced (tuber) yields. Zhang and Donnelley, (1997), also after working with potato found that plantlet growth parameters were not affected by $40 \mathrm{mM} \mathrm{NaCl}$, while 80 and $120 \mathrm{mM}$ $\mathrm{NaCl}$ significantly reduced all plantlet growth parameters compared with the control $(0 \mathrm{mM})$ and with each other, the only exception to this was root length which was similarly affected by 80 and $120 \mathrm{mM} \mathrm{NaCl}$ and less affected by salinity than the other growth parameters. It was also noticed that shoot tip necrosis increased by the increase of $\mathrm{NaCl}$ concentration in the medium, its scale was (2.6 in case of control treatment, and 3.3, 3.7, 4.2, and 4.7 in case of $\mathrm{NaCl}$ concentrations $(1462,2924,5848$, and $11696 \mathrm{ppm}$, respectively), this may be due to that Ca content that was decreased in NaCl- salt tolerant cells. There is a significant difference between treatment 1(control) and all treatments except treatment 2 (1462 ppm NaCl) (Piqueras et al., 1996).

Table 2: Effect of salinity stress on Coriander (Coriandrum sativum) seeds germination and growth.

\begin{tabular}{|c|c|c|c|c|c|c|c|c|}
\hline 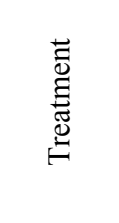 & 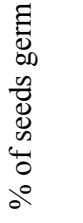 & 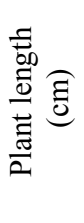 & $\begin{array}{l}\dot{0} \\
\stackrel{1}{0} \\
\stackrel{0}{0} \\
\stackrel{\Xi}{\Theta}\end{array}$ & 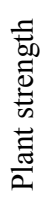 & $\begin{array}{l}\dot{0} \\
\stackrel{1}{0} \\
\dot{0} \\
\stackrel{0}{0}\end{array}$ & 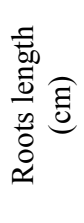 & 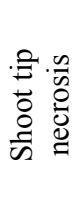 & 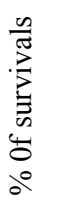 \\
\hline $\begin{array}{c}(1)^{*} \\
\text { Control }\end{array}$ & $99^{a^{* *}}$ & $13.4^{\mathrm{a}}$ & $14^{\mathrm{a}}$ & $5^{\mathrm{a}}$ & $16^{\mathrm{a}}$ & $5.6^{\mathrm{a}}$ & $0^{\mathrm{a}}$ & $98^{\mathrm{a}}$ \\
\hline$(2)$ & $76^{\mathrm{b}}$ & $9.8^{\mathrm{b}}$ & $8^{b}$ & $4^{b}$ & $11^{\mathrm{b}}$ & $4.9^{\mathrm{b}}$ & $0^{\mathrm{a}}$ & $70^{\mathrm{b}}$ \\
\hline (3) & $43^{c}$ & $5.3^{\mathrm{c}}$ & $4^{c}$ & $2^{c}$ & $5^{c}$ & $3^{c}$ & $1^{\mathrm{b}}$ & $32^{\mathrm{c}}$ \\
\hline (4) & $19^{\mathrm{d}}$ & $3.4^{\mathrm{d}}$ & $2^{\mathrm{d}}$ & $1^{\mathrm{d}}$ & $2^{\mathrm{d}}$ & $2.2^{\mathrm{d}}$ & $2^{c}$ & $11^{\mathrm{d}}$ \\
\hline (5) & $0^{\mathrm{e}}$ & $0^{\mathrm{e}}$ & $0^{\mathrm{e}}$ & $0^{\mathrm{e}}$ & $0.0^{\mathrm{e}}$ & $0.0^{\mathrm{e}}$ & $0^{\mathrm{d}}$ & $0^{\mathrm{e}}$ \\
\hline
\end{tabular}

$* 1=$ control $(0 \mathrm{ppm}), 2=1000 \mathrm{ppm}, 3=2000 \mathrm{ppm}, 4=3000 \mathrm{ppm}, 5=4000 \mathrm{ppm}$.

** different at $\mathrm{p}=0.05$. according to L.S.D.Means followed by the same letter in each column for each factor are not significantly. 
The results of the present study were in line with those of Munns and Termaat (1983), Munns (1993), Polturi and Prassad (1993), Jefferies (1996), Khodeir (2002), Joshi et al. (2012), Zeinolabedin (2012), and Moradi and Zavarech (2013). The results of this study also showed that coriander plants can resist $\mathrm{NaCl}$ salinity up to the concentration of $3000 \mathrm{ppm}$. However in a parallel study, Khodeir et al., 2013) demonstrated that dill (Anethum graveolens) seeds were more salt-tolerant than coriander plants, where they resist salinity till $4000 \mathrm{ppm} \mathrm{NaCl}$, while Coriander plants resist till $3000 \mathrm{ppm} \mathrm{NaCl}$ only.

In conclusion, all characters studied showed a progressive decrease as salinity levels increased. Coriander plants can withstand $\mathrm{NaCl}$ salinity up to the concentration of $3000 \mathrm{ppm}$. At the highest concentration $(4000 \mathrm{ppm})$ all the parameters of coriander failed to exist.

\section{REFERENCES}

Ashraf, M. (2009). Biotechnological approach of improving plant salt tolerance using antioxidants as markers. Biotech Adv 27: 84-93, c.f. Boyer, J. S. (1982). Plant productivity and environment. Science, 218: 443-448.

Boyer, J. S. (1982). Plant productivity and environment. Science, 218: 443-448.

Cha-um S.; Pokasombat Y.and Kirdmanee, C. (2011). Remediation of saltaffected soil by gypsum and farmyard manure-Importance for the production of Jasmine rice. Aust J Crop Sci 5: 458-465.

El - Barkouki, T. M. (2000). Studies of potato production by using tissue culture. Ph. D. dissertation. Faculty of Agriculture, Cairo University.

Epstein, E., J.D. Norlyn, D.W. Rush, R.W. Kinsbury, D.B. Kelly, G.A. Cunningham and A.F. Wrona, (1980). Saline culture of crops: A genetic approach. Sci., 210: $399-404$.

Essa,T.A.(2002). Effect of Salinity Stress on Growth and Nutrient Composition of Three Soybean (Glycine max L. Merrill) Cultivars. Journal of Agronomy and Crop Science. Volume 188, Issue 2, pages 86-93, April 2002.

FAO, (2002). Global network on integrated soil management for sustainable use of salt-affected soils. FAO Land and Plant Nutrition Management Services, Rome, Italy.

Hanson,J.B. (1984). The function of calcium in plant nutrition. In "Advances in Plant Nutrition" (P.B.Tinker and Leuchli, eds) pp.149-208.Prager, New York.

Jefferies, R.A., (1996). Evaluation of seedling selection for salinity tolerance in potato (Solanum tuberosum L.), Euphytica 88: 207-213.

Joshi,S.; Patel N.T.; Andey, I.B. and Pandey, A.N.(2012). Effect of supplemental $\mathrm{Ca} 2+$ on $\mathrm{NaCl}$-stressed castor plants (Ricinus communis L.). Acta Bot. Croat. 71 (1): 13-29.

Khan MA and Duke NC. (2001). Halophytes- A resource for the future. Wetland Ecology and Management, 6:455-456.

Khavari-Nejad, R.A. and Y. Mostofi, (1998). Effects of $\mathrm{NaCl}$ on photosynthetic pigments, saccharides and chloroplast ultrastructure in leaves of tomato cultivars. Photosynthetica, 35: 151-154.

Khodeir, A.E.S.S.E. (2002). Potato seeds production through plant tissue culture techniques. M.Sc. thesis. Faculty of Science, Menoufiya University, Egypt.

Khodeir, Alaa El-din Sayed; Akareb Abobakr, Hawa Benail and Mariam Imhammed (2013). Effect of salinity stress on Dill seeds germination and growth in vivo in Libya. Benghazi journal of science, 18-31, 2013. 
Klein, R.E. and Livingston, C. H. (1982). Eradication of potato virus X from potato by ribavirin treatment of cultured potato shoot-tips. American Potato Journal., 59: 359-365.

Leena, K.; Sharma, A. and Lodi, S. (2012). Potential health benefits of coriander (Coriandrum sativum): An overview. International journal of pharmaceutical research and development ( IJPRD), 2011; Vol 4 (2) : April -2012 (010-020).

Levy, D.; Fogelman, E. and Itzhak, Y. (1988). The effect of water salinity on potatoes (Solanum tuberosum L.) physiological indicies and yielding capacity. Potato Research, 31: 601-610.

Maghsoudi AM, Maghsoudi K. (2008). Salt stress effect on respiration and growth of germinated seeds of different Wheat (Triticum sativum L.) cultivars. World J Agri. Sci., 4(3): 351-358.

Moradi, P. and Zavareh, M. (2013). Effects of salinity on germination and early seedling growth of chickpea (Cicerarietinum L.) cultivars Intl. J. Farm. \& Alli. Sci., 2 (3): 70-74.

Morpurgo, R. (1991). Correlation between potato clones grown in vitro and under sodium chloride stress conditions. Plant Breeding, 107: 80-82.

Munns, R. (1993). Physiological processes limiting growth in saline soils: some dogmas and hypotheses. Plant, Cell and Environment, 16: 15-24.

Munns, R, and Termaat, A. (1986). Whole-plant responses to salinity. Australian Journal of Plant Physiology 13: 143-160.

Munns, R. (2005). Genes and salt tolerance: Bringing them together. Tansley. Rev. New Phytol., 167: 645-663.

Nasser J.Y. Sholi (2012). Effect of Salt Stress on Seed Germination, Plant Growth, Photosynthesis and Ion Accumulation of four Tomato Cultivars. American Journal of Plant Physiology, 7: 269-275.

Piqueras, A., J. Hernandez, E. Olmos, E. Hellin and F. Sevilla, (1996). Changes in antioxidant enzyme and organic solutes associated with adaptation of Citrus cells to salt stress. Plant Cell, Tissue and Organ Culture, 45: 53-60.

Polturi, S.D.P. and Prassad, P.V.D. (1993). Influence of salinity on axillary bud cultures of six lowland tropical varieties of potato (Solanum tuberosum L.). Plant Cell, Tissue and Organ Culture. 32: 2, 185-191.

SAS, (1990). Users guide: Statistic version 6, forth edition. 1990. SAS Inst., Inc., Cary, NC.

Zeinolabedin, J. (2012). The Effects of Salt stress on plant growth. Technical Journal of Engineering and Applied Sciences (TJEAS) -2 (1):7-10.

Zhang, Y. and Donnelly, D. (1997). In vitro bioassays for salinity tolerance screening of potato. Potato Research 40: 285-295. Selskokhozyaist vennaya biologia 13 (4): 512-516. 
Alaa El-Din Sayed Ewase et al.

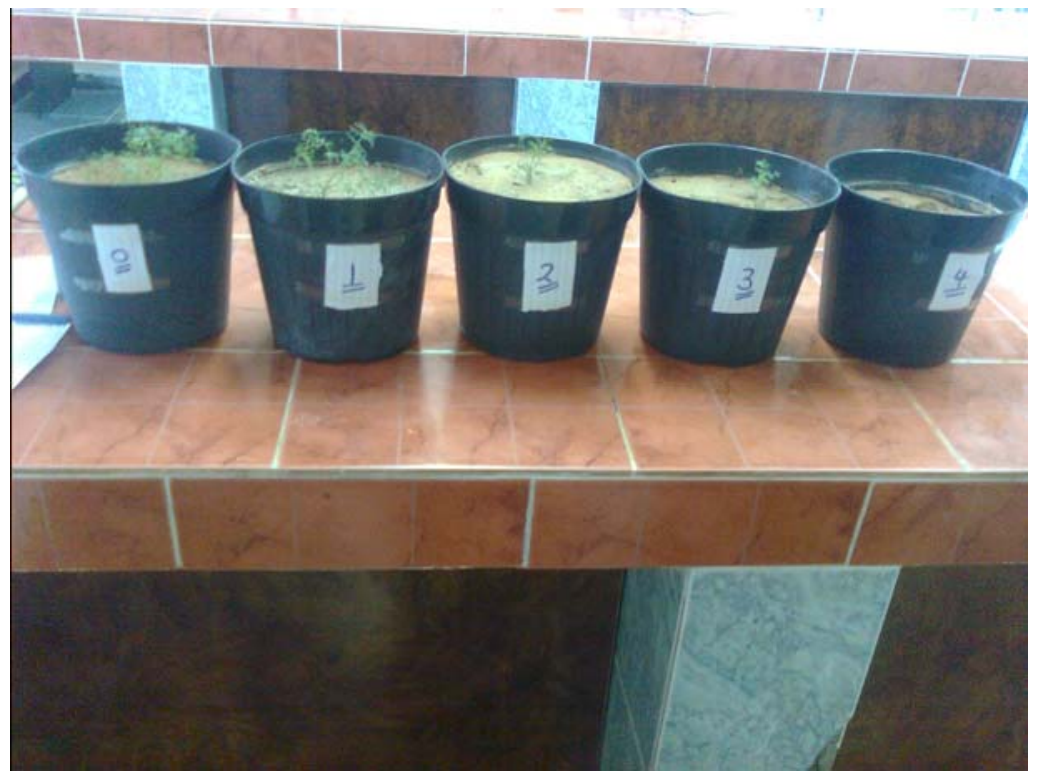

Fig. 2: Different treatments of Coriander plants grown in pots.

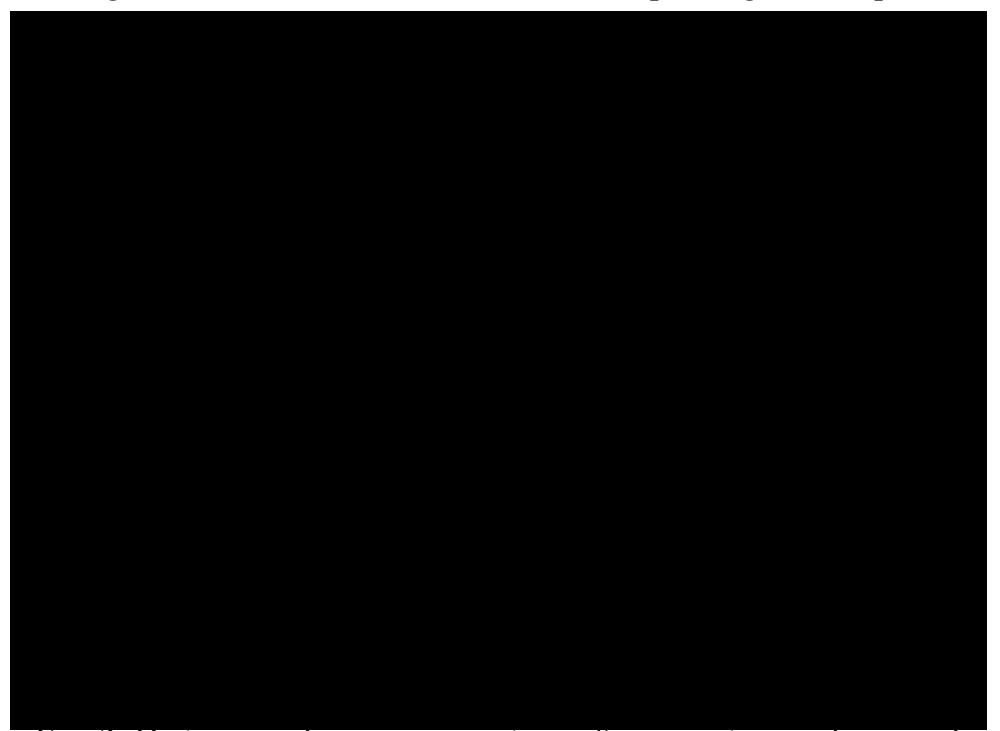

Fig. 3: Histogram showing percentage of germination and survivals.

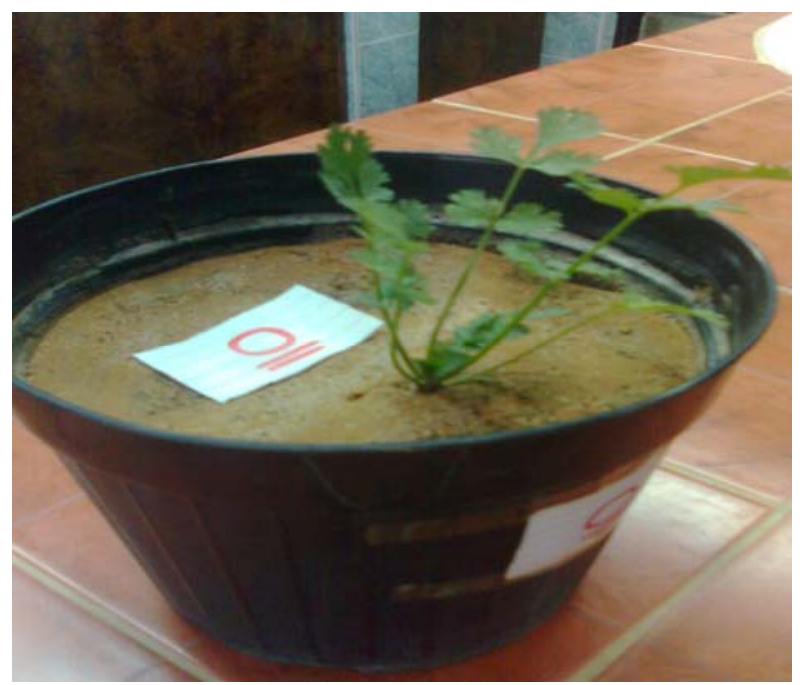

Fig. 4: A Coriander control plant ( $0 \mathrm{ppm} \mathrm{NaCl).}$ 


\section{ARABIC SUMMARY}

$$
\text { تأثير الملوحة على إنبات و نمو بذور نبات الكسبر. }
$$

علاء الدين سيا سيا عويس *، سميرة عمران ، سعاد الشريف و نجاة توفيق .

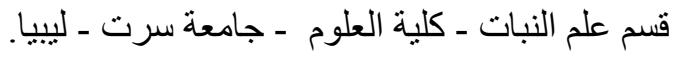

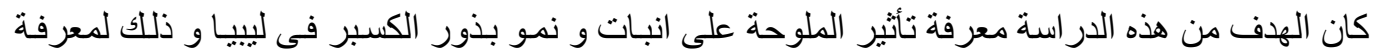

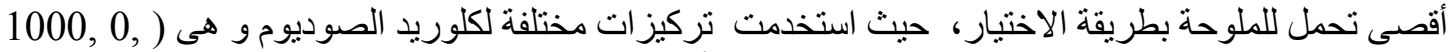

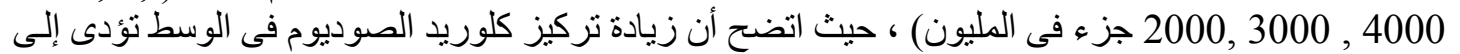

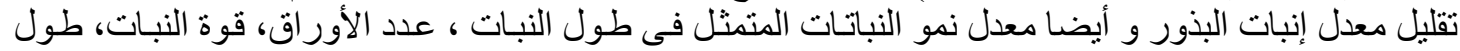

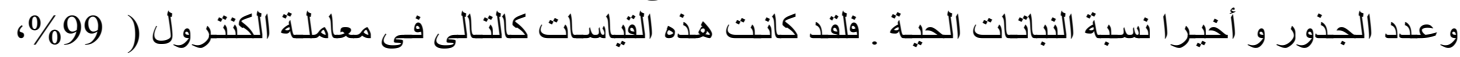

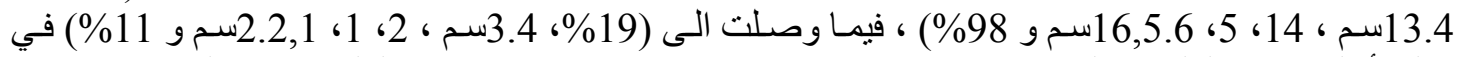

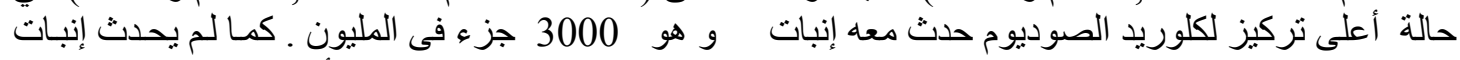

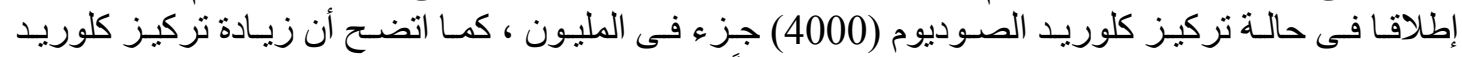

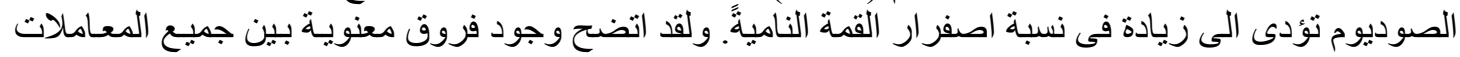

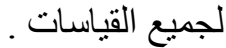

